\title{
Power Estimation of HCFV Based on Voyage Profile
}

\author{
P.I. Santosa ${ }^{1}$, I.K.A.P Utama ${ }^{2}$, W.D Aryawan ${ }^{3}$ \\ Department of Naval Architecture and Shipbuilding Engineering, Institut Teknologi Sepuluh Nopember (ITS) Surabaya, Indonesia
}

\begin{abstract}
The hybrid technology, when applicable for sea transportation, is a way to reduce the use of fossil fuels and toxic gases. The hybrid power of catamaran fishing vessel (HCFV) is designed to use a combination power by using engine electric and sail. The configuration consist of individual power and combined power (diesel engine and sail, diesel engine and solar panels, and sail, solar panels and diesel engine). The method of power estimation using the experiment result of catamaran resistance in towing tank [1], and followed by calculating the thrust requirement ( $T$ req.) and estimating the energy of power (P req.) of individual and later the combined power based on fishing vessel transportation mode in order to find out the optimum and demonstrated configuration of hybrid system. The current study is carried out in order to minimize the use of energy from fossil fuels and produce cleaner seas environment. The varying voyage speed are: depature from por/Arrival at Port 3 knots, Outward bound/Homeward bound 9.8 knots and on fishing ground 7 knots. The result of combining propulsion systems at sailing speed 3 knots with the optimum configuration was found in combination no 8 (Engine + Panel + Solar sail) and give emission index of 0,016, , at fishing speed 7 knots and produces emission index of 0.05 and finally, at sailing speed 9.8 knots give emission index of 0.14
\end{abstract}

Keywords: HCFV; hybrid technology; power estimation;engine, solarpanel, sail, emission

\section{Introduction}

A fishing vessel is a boat or ship used to catch fish in the sea, or on a lake or river [2]. According to the FAO, there are currently four million commercial fishing vessels. About 1.3 million of these are decked vessels with enclosed areas. Nearly all of these decked vessels are mechanized, and 40,000 of them are over 100 tons. At the other extreme, twothirds (1.8 million) of the undecked boats are traditional craft of various types, powered only by sail and oars [2]. Their catch provides daily foods for millions of people worldwide. It is recently reported that there is an increase on toxic gases such as $\mathrm{CO}_{2}, \mathrm{SO}_{2}$ and $\mathrm{NO}_{\mathrm{X}}$ to the atmosphere, particularly with the use of diesel engine together with its fossil fuels. Given the impact of fishing, it is an important activity to enhance and align fishing operations with environmentally friendly practices [3]. Factors driving fishing vessel operational, in general, are economic and environmental issues. The main economic concern, in particular, is fuel costs and the main environmental issue amounts to emissions and pollution [4].

Normally voyage profile and sailing speed of fishing vessel in the world are: i) depature from por/Arrival at Port 3 knots, ii) Outward bound/Homeward bound 9.8 knots and iii)on fishing ground 7 knots [5].

Many efforts have been made to help the fishermen especially in order to reduce the use of fossil fuel. Several power systems have been developed including the combination of engine and sail which is later known as sail assisted engine [6]. The powering vessel without using engine and fuel oil later becomes more popular considering environmental issues known as green economy concept. There are several choices of power systems such as the use of sail, solar power and the combination of the two and three power systems [6].
The idea of developing HCFV appears from economic and environmental pressures thus combine to create the need for a fresh appraisal of the estimation of ship propulsive power and the choice of suitable machinery [4]. Economic factors such as changing fuel costs and environmental issues such as emission and pollution, all ultimately lead to the need to minimize ship propulsive power [4].

Figure 1 shows layout of the developed HCFV (with use power combination: engine, sail, photovoltaic). The large deck space is a key feature of catamaran fishing vessel, which provides an incredible amount of spaces for accommodation, bridge, engine room and massive fish storage. The current paper is attempted to develop the research from [3], with considering the environmental concern from the application of photovoltaic and sail in order to reduce the size of main engine for emission reduction purposes.

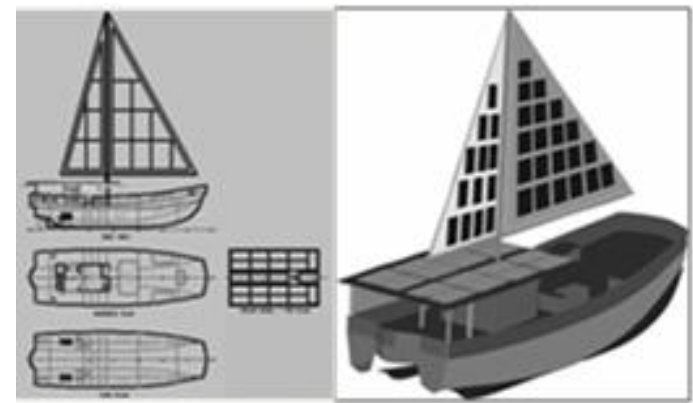

Figure 1: The Hybrid Catamaran Fishing Vessel

\section{Power Estimation Methodology}

The hybrid power of catamaran fishing vessel is designed to use an individual and combination of power by using conventional engine, PV panels and sail. It is firstly carried out by using the experiment result of catamaran resistance in towing tank [1], and followed by calculating the thrust requirement (T req.) and estimating the energy of power $(P$ 


\section{International Journal of Science and Research (IJSR) \\ ISSN (Online): 2319-7064 \\ Index Copernicus Value (2013): 6.14 | Impact Factor (2015): 6.391}

req.) of individual and later the combined power (diesel engine and sail, diesel engine and solar panels, sail and solar panels and diesel engine, sail and solar panels) in order to find out the optimum hybrid system at varying sailing speed. Furthermore, investigation is extended to the analysis of the reduction of $\mathrm{CO}_{2}$ Index, which used the formulation of fishing vessel approach proposed by [3].

\subsection{Data's set up}

Given: the particular of catamaran and the result of experiment are shown in Tables 1 and 2, respectively, which is summarized from the work done in [1]:

Table 1: Particulars of catamaran

\begin{tabular}{|c|c|c|}
\hline Parameter & Catamaran & Demihull \\
\hline LWL $(\mathrm{m})$ & 14.5 & 14.5 \\
B $(\mathrm{m})$ & 7.118 & 1.318 \\
H $(\mathrm{m})$ & 1.44 & 1.44 \\
D (m) & 0.694 & 0.694 \\
C $_{\mathrm{B}}$ & 0.432 & 0.432 \\
Displ. (ton) & 11.8 & 5.9 \\
\hline
\end{tabular}

Table 2: Experiment result of catamaran resistance

\begin{tabular}{|c|c|r|r|r|r|}
\hline Run & \multirow{2}{*}{$\begin{array}{c}\text { V } \\
\text { No. }\end{array}$} & \multirow{2}{*}{ Fr } & \multicolumn{3}{|c|}{ Catamaran Resistances $(\mathrm{kN})$} \\
\cline { 4 - 6 } & & & $\mathrm{S} / \mathrm{L}=0.2$ & $\mathrm{~S} / \mathrm{L}=0.3$ & $\mathrm{~S} / \mathrm{L}=0.4$ \\
\hline 1 & 5.788 & 0.250 & 1.821 & 1.659 & 1.659 \\
\hline 2 & 6.218 & 0.268 & 2.141 & 1.851 & 2.061 \\
\hline 3 & 6.677 & 0.288 & 2.443 & 2.239 & 2.348 \\
\hline 4 & 7.051 & 0.304 & 2.852 & 2.678 & 2.947 \\
\hline 5 & 7.560 & 0.326 & 3.460 & 3.568 & 3.547 \\
\hline 6 & 8.032 & 0.347 & 4.467 & 3.954 & 3.766 \\
\hline 7 & 8.384 & 0.362 & 4.844 & 4.345 & 4.341 \\
\hline 8 & 8.818 & 0.380 & 5.149 & 4.790 & 4.662 \\
\hline 9 & 9.233 & 0.398 & 5.807 & 5.592 & 5.515 \\
\hline 10 & 9.813 & 0.423 & 7.101 & 6.448 & 6.138 \\
\hline
\end{tabular}

\subsection{Decision variables}

\subsubsection{Ship Moving Theory}

The overall concept of the powering system may be seen as converting the energy of the fuel into useful thrust ( $T$ req.) to match the ship resistance $(R T)$ at the required speed $(V S)$ as shown in Figure 2.

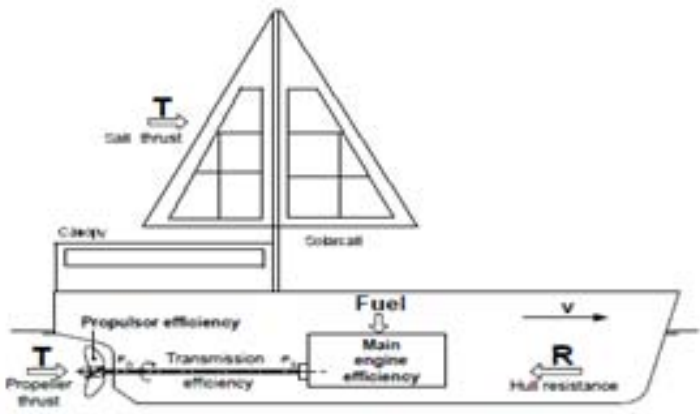

Figure 2: Concepts of energy conversion

Based on the above concept, the requirement of ship moving is

$$
T \geq R_{T} \quad \text { or } \quad T-R_{T} \geq 0
$$

To propel itself, the HCFV applies a combination various propulsors, which convert the power (engine electric) into useful thrust throughout: propeller and sail.

Where:

$$
\text { Treq. }=\text { T propeller }+T \text { sail }
$$

T propeller is thrust of propeller, $T$ sail is thrust of sail

Hence

$$
T \text { propeller }+ \text { T sail } \geq R_{T}
$$

This is later developed to power small vessels under a combined power known as hybrid system.

\subsubsection{Catamaran Resistance}

The most widely used estimation of catamaran resistance is the method proposed by Insel and Molland [8]. In this case, catamaran hull consists of 2 isolated demihulls and creates wave and viscous resistance interference and formulated as follows:

$$
C_{T}=(1+\phi k) \sigma C_{F}+\tau C_{W}
$$

Where:

$\mathrm{C}_{\mathrm{T}}$ is total resistance coefficient, $\mathrm{C}_{\mathrm{F}}$ is frictional resistance coefficient and obtained from ITTC-1957 correlation line, $\mathrm{C}_{\mathrm{W}}$ is wave resistance coefficient of isolated demihull, $(1+\mathrm{k})$ is form factor value of isolated demihull, $\varnothing$ is used to estimate the change of pressure around demihull, $\sigma$ represents additional velocity between demihulls and calculated from the summation of local frictional resistance around wetted surface area. In fact, the factors of $\varnothing$ and $\sigma$ are difficult to measure hence for the practical purposes, the two factors can be combined to form viscous resistance interference factor $\beta$ where $(1+\phi k) \sigma=(1+\beta k)$ hence:

$$
C_{T}=(1+\beta k) C_{F}+\tau C_{W}
$$

Where for monohull or demihull at isolation the value of $\beta=1$ and $\tau=1$

$$
\begin{aligned}
& \text { Hull resistance, } R_{H}=1 / 2 . \rho \cdot C_{T} \cdot S \cdot V^{2} \\
& \text { Air drag, } D_{\text {air }}=C_{D} \cdot 1 / 2 . \rho \cdot A_{T} \cdot V^{2} \\
& \text { Total resistance, } R_{T}=R_{H}+D_{\text {air }}
\end{aligned}
$$

\subsubsection{Thrust}

Thrust is energy or force that required to propel the ship and can be expressed as the following equation [7]:

$$
\text { T req. }=R_{T} /(1-t)
$$

Where $t$ is thrust deduction factor and (for single screw) may be calculated as [7]:

$$
t=k_{R} \cdot w t
$$

$w_{T}=-0.0458+0.3745 C_{B}{ }^{2}+0.1590 D_{w^{-}}-0.8635 F r+1.4773 F^{2}$

$D_{w}=\frac{B}{\nabla^{1} y^{x}} \sqrt{\frac{\nabla^{1} y^{3}}{D}}$

Where: $k_{R}$ is 0.5 for thin rudder, $w_{T}$ is wake fraction, $C_{B}$ is block cefficient, $F r$ is Froude number, $D w$ is wake fraction parameter, $\nabla$ is vessel displacement, B is breadth, $\mathrm{D}$ is depth.

\subsubsection{Powering}

There are several types of propulsion, which can be used to assess the efficiency of propulsion and may be described as follows:

\subsubsection{Conventional Engine}

One fundamental division in conventional powering methods is the distinguish between the effective power required to drive the vessel and power delivered to the propulsion unit(s) [7]. 


\section{International Journal of Science and Research (IJSR) \\ ISSN (Online): 2319-7064 \\ Index Copernicus Value (2013): 6.14 | Impact Factor (2015): 6.391}

Effective power $(P E)=R_{T} x V_{S}$

Delivered power $(P D)=P E / \eta D$

Quasi propulsive coefficient $(\eta D)=\eta P . \eta H . \eta R$

where: Open water efficiency $(\eta P)$, Hull efficiency $(\eta H)=(1$ $t) /\left(1-w_{T}\right)$, Relative rotative efficiency $(\eta R)$

Service power $(P s)=P D / \eta T$

$\eta \mathrm{T}$ is 0,95 with gearbox, 0,98 without gearbox

Installed power $(P I)=P s+$ Margin

Margins (roughness, fouling, weather) $15-20 \%$ depend on service and route.

\subsubsection{Photovoltaic Panels}

When a PV system is installed in a vessel, some obstacles must be overcome to extract the most power from the PV panels. A photovoltaic panel harvests most energy out of sun and then stores into battery. The energy is then used to power (electric engine) to propel the vessels into certain distance at certain speed [9]. The vessel is powered by battery and the $\mathrm{PV}$ power is applied to charge the battery during operational at sea. In this case, PV panels are placed on roof and sail as a solar sail. The solar sail has double function, namely producing the driving force in the direction of the motion and capturing energy from sun-rays.

$$
\begin{gathered}
\text { Power requirement: } \mathrm{P}=\mathrm{V} \times \mathrm{I} \\
\text { Pmax }=\text { Voc } \times \text { Isc } \times \mathrm{FF} \\
\text { Fill Factor: FF }=\frac{\text { Vmp } \times \text { Imp }}{\text { Voc } \times \text { Isc }} \\
\text { P watt peak }=\text { PV area } \times \text { PSI } \times \eta p v
\end{gathered}
$$

Where: Pmax : Power maximum (W), Voc: Open circuit voltage (V), Isc: Short circuit current (A), FF: Fill Factor, PV area : Photovoltaic area $\left(\mathrm{m}^{2}\right)$, PS: Peak Solar Insolation 1000 $\mathrm{W} / \mathrm{m}^{2}, \eta p v$ : efficiency Photovoltaic

\subsubsection{Sail}

A sail is defined as a surface, typically made of fabric and supported by a mast with purpose to propel a sailing vessel [11]. In estimating the performance of a sailing vessel, it is necessary to predict the forces generated by the sails [13].

$$
\text { Driving force }(T s)=q \text {. As }
$$

Where : Dynamic wind pressure $(\mathrm{q})=1 / 2 \times \rho \times £ \times \mathrm{v}_{\mathrm{w}}{ }^{2}$ (ton $\left./ \mathrm{m}^{2}\right)$, Air mass density $(\rho)=\gamma / \mathrm{g}$, Weight per unit volume $(\gamma)=1.2265 \mathrm{t} / \mathrm{m}^{3}, \mathrm{~g}=$ Acceleration of gravitation $\left(9.81 \mathrm{~ms}^{-2}\right)$, $£=$ Wind pressure Coeff. (1.1), Wind speed $\left(\mathrm{v}_{\mathrm{w}}\right)$, Sail area ( As).Practically, all boats have a sail ratio (SR) which sail area $(A s) /$ wetted surface (WSA) between 2.0 and 2.5, the mean value is 2.25 [11]. Using the graph of sail ratio shown in Figure 3, sail ratio depends on LWL of the vessel [12]. The choice of sail arrangement and underwater hull and appendage design can make a large difference in available speed for given wind directions and magnitudes [13]. However, in reality this depends not only on the apparent wind speed and direction and the sail characteristics, but also on the skill of sailor in trimming the sails for the prevailing conditions [7].

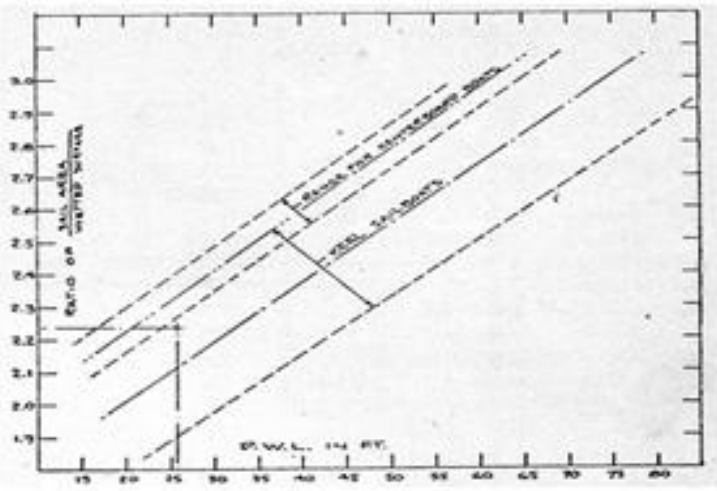

Figure 3: Sail Ratio as a function of LWL [10]

\subsubsection{The combination of power}

There are several power combination, which will be used in the HCFV, including diesel engine and sail; diesel engine and PV panels; sail, PV panels and diesel engine; solar sail, $\mathrm{PV}$ panels and diesel engine [6].

\subsubsection{Quantifying Environmental Impact}

The emissions from ships include $\mathrm{NO}_{\mathrm{X}}, \mathrm{SO}_{\mathrm{X}}$ and $\mathrm{CO}_{2} . \mathrm{CO}_{2}$ emissions have a global climate impact and a concentrated effort is being made worldwide towards their reduction. In order to monitor and quantify $\mathrm{CO} 2$ emissions, research from [3] explored about an estimation of greenhouse gasses per $\mathrm{kg}$ for fishing vessel. The general form of the Emission Index $(E I)$ for fishing vessel, as proposed:

$$
E I=K i \cdot S F R \cdot K w T \cdot \gamma\left(\mathrm{kg} / \text { day of } \mathrm{CO}_{2}\right)
$$

For example: Ki $3170 \mathrm{Kg} / \mathrm{Ton}$ fuel, SFR $0.19 \mathrm{Kg} / \mathrm{Kw} . \mathrm{hr}$, ship power $(\mathrm{kW}) 60 \mathrm{~kW}, \mathrm{~T} 8 \mathrm{hrs}, \gamma 0.03206$ tons $/ \mathrm{kg}$ (Diesel Oil type). By using Equation (20), it can be found that the Emission Index for fishing vessel (EI) $9,268 \mathrm{~kg} /$ day of $\mathrm{CO}_{2}$. It means that the HCFV using $60 \mathrm{~kW}$ diesel engine as converting the energy of the fossil fuels into useful thrust $(T)$ to match the ship resistance (RT) at the required speed $(V s)$ and produce $9,268 \mathrm{~kg}$ /day of $\mathrm{CO}_{2}$ pollutant. The current results give an estimate on the basis of ton of fuel burned times the factor $K i$ for exhaust gas and reflect the present fishing vessel operations where a fishing boat is assumed to be operated 8 hours per day.

\section{Results}

\subsection{Output Parameters}

The results of total resistance $\left(R_{T}\right)$ produced by (7), thrust requirement ( $T$ req.) calculated by (8), (9) and power requirement (P req.) estimated by (14) as shows in Table 3. 


\section{International Journal of Science and Research (IJSR) \\ ISSN (Online): 2319-7064}

Index Copernicus Value (2013): 6.14 | Impact Factor (2015): 6.391

Table 3: Result of decision variables data's processing

\begin{tabular}{|c|c|c|c|c|c|c|c|c|c|c|c|c|}
\hline \multirow{2}{*}{ No } & \multirow{2}{*}{$\begin{array}{l}\text { Source } \\
\text { power }\end{array}$} & \multirow{2}{*}{ Vs (kts) } & \multirow{2}{*}{$R T(k N)$} & \multirow{2}{*}{$\operatorname{Treq}(\mathrm{kN})$} & \multicolumn{3}{|c|}{ Thrust supply (kN) } & \multicolumn{3}{|c|}{ Power supply $(\mathrm{kW})$} & \multicolumn{2}{|c|}{$E I(K g / d a y)$} \\
\hline & & & & & $\mathbf{E}$ & $\mathbf{P}$ & $\mathbf{S}$ & $\mathbf{E}$ & $\mathbf{P}$ & $\mathbf{S}$ & $\mathrm{CO}_{2}$ & Index \\
\hline 1 & Engine $(\mathrm{E})$ & \multirow{8}{*}{3} & \multirow{8}{*}{0.11} & \multirow{8}{*}{0.115} & 0.115 & 0 & 0 & 7,04 & 0 & 0 & 1088 & 0,117 \\
\hline 2 & Panel (P) & & & & 0 & 0.115 & 0 & 0 & 7,04 & 0 & 0 & 0 \\
\hline 3 & Sail (S) & & & & 0 & 0 & 0.115 & 0 & 0 & 7,04 & 0 & 0 \\
\hline 4 & $E+P$ & & & & 0.095 & 0.02 & 0 & 5,82 & 1,22 & 0 & 899 & 0,097 \\
\hline 5 & $E+S$ & & & & 0.046 & 0 & 0.069 & 2,83 & 0 & 4,21 & 437 & 0,047 \\
\hline 6 & $\mathrm{P}+\mathrm{S}$ & & & & 0 & 0.02 & 0.095 & 0 & 1,22 & 5,82 & 0 & 0 \\
\hline 7 & $\mathrm{E}+\mathrm{P}+\mathrm{S}$ & & & & 0.049 & \begin{tabular}{|l|}
0.02 \\
\end{tabular} & 0.046 & 2,98 & 1,22 & 2,84 & 461 & 0,050 \\
\hline 8 & $\mathrm{E}+\mathrm{P}+\mathrm{SS}$ & & & & \begin{tabular}{|l|}
0.017 \\
\end{tabular} & 0.052 & 0.046 & 0,98 & 3,22 & 2,84 & 151 & 0,016 \\
\hline
\end{tabular}

\subsection{Mathematic model}

Total resistance, $R T=35.99 \mathrm{Fr} 2+1.633 \mathrm{Fr}-0.698$

Thrust requirement, Treq. $=37.85 \mathrm{Fr} 2+1.717 \mathrm{Fr}-0.736$

Power requirement, $P$ req $=852.2 \mathrm{Fr} 2-289.9 \mathrm{Fr}+30.26$

3.2.1 Mathematic model of Energy supply of $\mathrm{HCFV}$ on depature from port/Arrival Port at sailing speed 3 knots

Thrust requirement (T req.)

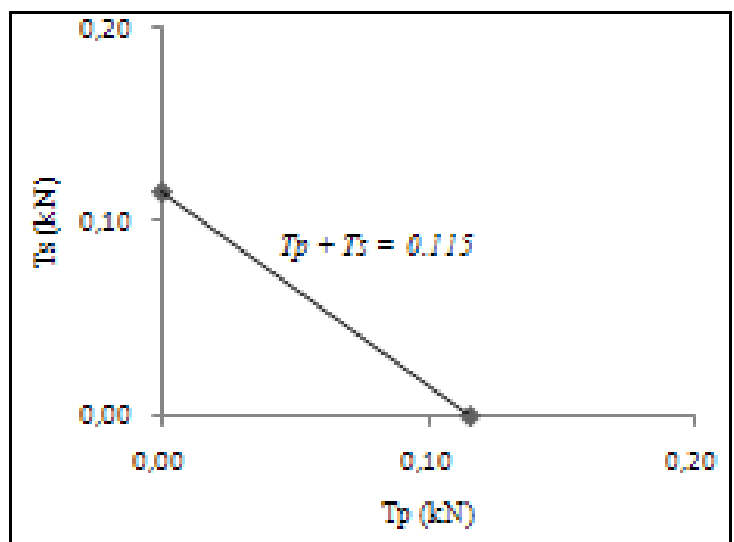

Figure 4: Correlation between $T p$ and $T s$ at $V s 3$ knots

Power requirement (P req.)

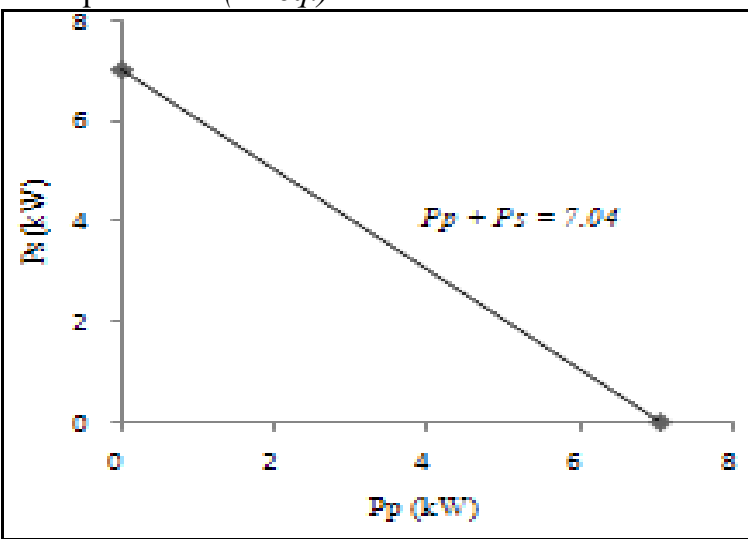

Figure 5: Correlation between $P p$ and $P s$ at $V s 3$ knots
Table 4: Energy supply of Power Combination at $V_{S} 3$ knots

\begin{tabular}{|c|c|c|c|c|c|c|c|}
\hline $\begin{array}{c}\text { Run } \\
\text { No. }\end{array}$ & $V s(\mathrm{kts})$ & $F r$ & $\begin{array}{c}R_{H}, \\
\text { S/L0.4, } \\
(\mathrm{kN})\end{array}$ & $\begin{array}{c}D_{\text {air }} \\
(\mathrm{kN})\end{array}$ & $\begin{array}{c}R T \\
(\mathrm{kN})\end{array}$ & $\begin{array}{c}\text { Treq. } \\
(\mathrm{kN})\end{array}$ & $\begin{array}{c}\text { Preq. } \\
(\mathrm{kW})\end{array}$ \\
\hline 1 & 5.788 & 0.25 & 1.659 & 0.294 & 1.953 & 2.059 & 11.05 \\
\hline 2 & 6.218 & 0.268 & 2.061 & 0.294 & 2.355 & 2.443 & 13.78 \\
\hline 3 & 6.677 & 0.288 & 2.348 & 0.294 & 2.642 & 2.898 & 17.45 \\
\hline 4 & 7.051 & 0.304 & 2.947 & 0.294 & 3.241 & 3.284 & 20.89 \\
\hline 5 & 7.56 & 0.326 & 3.547 & 0.294 & 3.841 & 3.846 & 26.32 \\
\hline 6 & 8.032 & 0.347 & 3.766 & 0.294 & 4.06 & 4.417 & 32.28 \\
\hline 7 & 8.384 & 0.362 & 4.341 & 0.294 & 4.635 & 4.846 & 36.99 \\
\hline 8 & 8.818 & 0.38 & 4.662 & 0.294 & 4.956 & 5.382 & 43.16 \\
\hline 9 & 9.233 & 0.398 & 5.515 & 0.294 & 5.809 & 5.943 & 49.87 \\
\hline 10 & 9.813 & 0.423 & 6.138 & 0.294 & 6.432 & 6.763 & 60.12 \\
\hline
\end{tabular}

3.2.2 Mathematic model of Energy supply of $\mathrm{HCFV}$ on fishing ground at fishing speed 7 knots

Thrust requirement (T req.)

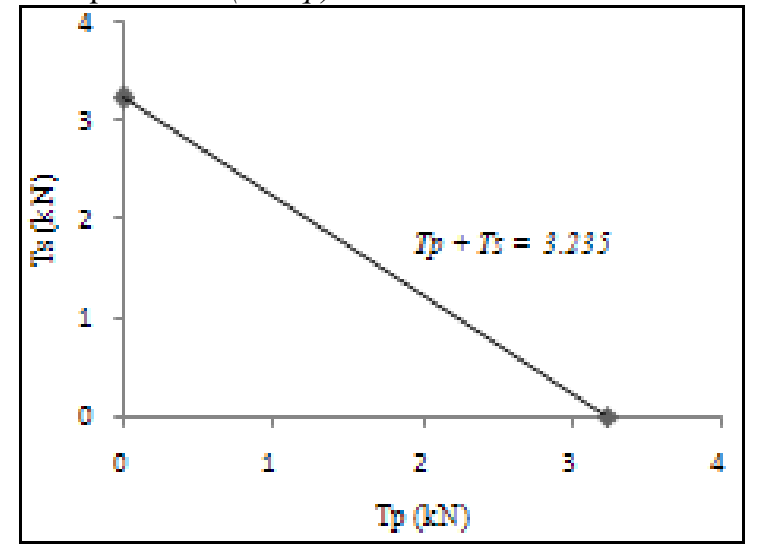

Figure 6: Correlation between $T p$ and $T s$ at $V_{S} 7$ knots

Power requirement (P req.)

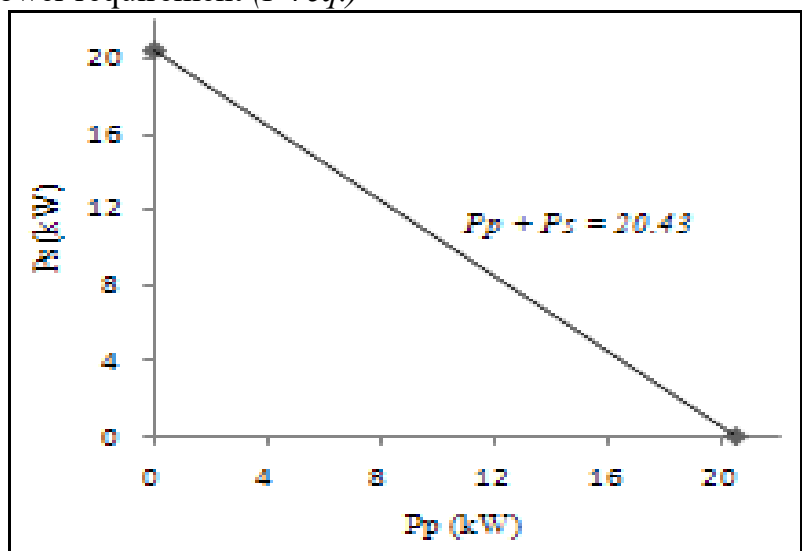

Figure 7: Correlation between $P p$ and $P s$ at $V s 7$ knots

Volume 5 Issue 7, July 2016

www.ijsr.net

Licensed Under Creative Commons Attribution CC BY 


\section{International Journal of Science and Research (IJSR) \\ ISSN (Online): 2319-7064}

Index Copernicus Value (2013): 6.14 | Impact Factor (2015): 6.391

Table 5: Energy supply of Power Combination at $V_{S} 7$ knots

\begin{tabular}{|c|c|c|c|c|c|c|c|c|c|c|c|c|}
\hline \multirow{2}{*}{ No } & \multirow{2}{*}{ Source power } & \multirow{2}{*}{$V s(k t s)$} & \multirow{2}{*}{$R T(k N)$} & \multirow{2}{*}{ Treq $(k N)$} & \multicolumn{3}{|c|}{ Thrust supply $(k N)$} & \multicolumn{3}{|c|}{ Power supply $(\mathrm{kW})$} & \multicolumn{2}{|c|}{$E I($ Kg/day $)$} \\
\hline & & & & & $\mathbf{E}$ & $\mathbf{P}$ & $\mathbf{S}$ & $\mathbf{E}$ & $\mathbf{P}$ & $\mathbf{S}$ & $\mathrm{CO}_{2}$ & Index \\
\hline 1 & Engine (E) & \multirow{8}{*}{7} & \multirow{8}{*}{3,241} & \multirow{8}{*}{3,358} & 3,358 & 0 & 0 & 21,77 & 0 & 0 & 3363 & 0,36 \\
\hline 2 & Panel (P) & & & & 0 & 3,358 & 0 & 0 & 21,77 & 0 & 0 & 0 \\
\hline 3 & Sail (S) & & & & 0 & 0 & 3,358 & 0 & 0 & 21,77 & 0 & 0 \\
\hline 4 & $E+P$ & & & & 2,775 & 0,583 & 1,205 & 17,99 & 3,78 & 0 & 2779 & 0,30 \\
\hline 5 & $E+S$ & & & & 1,352 & 0 & 1,536 & 8,77 & 0 & 13,00 & 1354 & 0,15 \\
\hline 6 & $\mathrm{P}+\mathrm{S}$ & & & & 0 & 0,583 & 1,352 & 0 & 3,78 & 17,99 & 0 & 0,00 \\
\hline 7 & $\mathrm{E}+\mathrm{P}+\mathrm{S}$ & & & & 1,423 & 0,583 & 1,205 & 9,23 & 3,78 & 8,76 & 1425 & 0,15 \\
\hline 8 & $\mathrm{E}+\mathrm{P}+\mathrm{SS}$ & & & & 0,470 & 1,536 & 1,536 & 3,06 & 9,95 & 8,76 & 472 & 0,05 \\
\hline
\end{tabular}

3.2.2 Mathematic model of Energy supply of $H C F V$ on outward bound/homeward bound at service speed 9.8 knots

Thrust requirement (T req.)

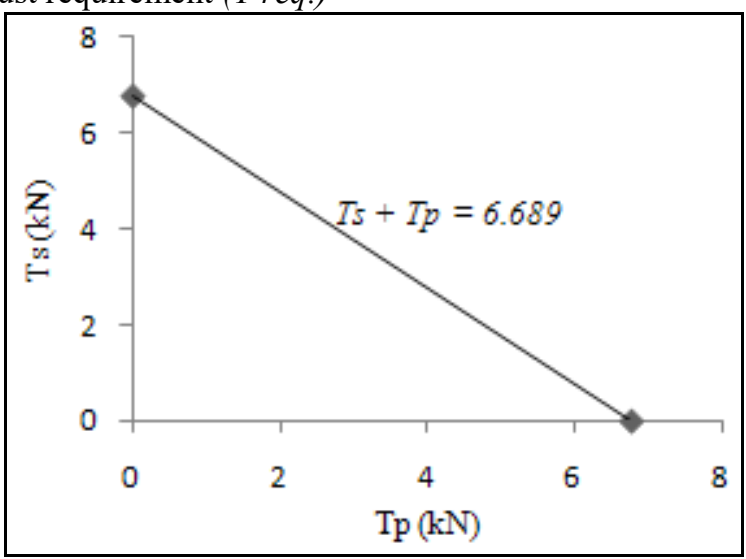

Figure 8: Correlation between $T p$ and $T s$ at $V s 9.8$ knots
Power requirement (P req.)

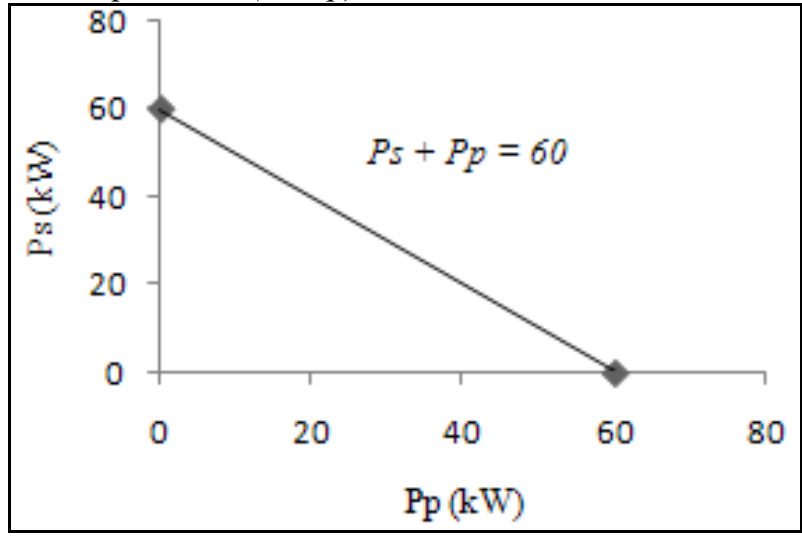

Figure 9: Correlation between $P p$ and $P S$ at $V_{S} 9.8$ knots

Table 6: Energy supply of Power Combination at $V_{S} 9.8$ knots

\begin{tabular}{|c|c|c|c|c|c|c|c|c|c|c|c|c|}
\hline \multirow{2}{*}{$\mathrm{No}$} & \multirow{2}{*}{ Source power } & \multirow{2}{*}{$V s(k t s)$} & \multirow{2}{*}{$R T(k N)$} & \multirow{2}{*}{$\operatorname{Treq}(k N)$} & \multicolumn{3}{|c|}{ Thrust supply (kN) } & \multicolumn{3}{|c|}{ Power supply $(\mathrm{kW})$} & \multicolumn{2}{|c|}{ EI (Kg/day) } \\
\hline & & & & & $\mathbf{E}$ & $\mathbf{P}$ & $\mathbf{S}$ & $\mathbf{E}$ & $\mathbf{P}$ & $\mathbf{S}$ & $\mathrm{CO}_{2}$ & Index \\
\hline 1 & Engine $(\mathrm{E})$ & \multirow{8}{*}{9.8} & \multirow{8}{*}{6.43} & \multirow{8}{*}{6,689} & 6,689 & 0 & 0 & 60 & 0 & 0 & 9268 & 1 \\
\hline 2 & Panel (P) & & & & 0 & 6,689 & 0 & 0 & 60 & 0 & 0 & 0 \\
\hline 3 & Sail (S) & & & & 0 & 0 & 6,689 & 0 & 0 & 0 & 0 & 0 \\
\hline 4 & $E+P$ & & & & 5,527 & 1,162 & 2,399 & 49.58 & 10.42 & 0 & 7659 & 0.83 \\
\hline 5 & $E+S$ & & & & 2,693 & 0 & 3,060 & 24.16 & 0 & 35.84 & 3732 & 0.4 \\
\hline 6 & $\mathrm{P}+\mathrm{S}$ & & & & 0 & 1,162 & 2,693 & 0 & 10.42 & 49.58 & 0 & 0 \\
\hline \begin{tabular}{|l|}
7 \\
\end{tabular} & $E+P+S$ & & & & 2,834 & 1,162 & 2,399 & 25.43 & 10.42 & 24.15 & 3929 & 0.42 \\
\hline 8 & $\mathrm{E}+\mathrm{P}+$ Solar $\mathrm{S}$ & & & & 0,937 & 3,059 & 3,060 & 8.42 & 27.43 & 24.15 & 1301 & 0.14 \\
\hline
\end{tabular}

\section{Discussion}

The first discussion is how the $H C F V$ demonstrate the potential for using renewable energy on voyage:

1) Departure from port: the vessel in light weight condition at sailing speed 3 knots. Here, the vessel needed thrust ( $T$ req.) around $0.115 \mathrm{kN}$ to equalize the ship resistance $(R T)$ $0.112 \mathrm{kN}$ and required power ( $P$ req.) is $7.04 \mathrm{~kW}$. To fulfill Preq., the $H C F V$ possible using powered, as follows: in bad condition, the vessel powered by engine $(7.04 \mathrm{~kW})$, it produces emission index (EI) of 1,088 $\mathrm{kg} /$ day of $\mathrm{CO}_{2}$. In good condition, possible uses all configuration as shown in Table 4. The optimum powered could be achieved when the vessel used combination no 8 (engine, panels and solar sail) because the $E I$ is 0,016 .

2) Outward bound: the vessel still in light weight condition at sailing speed Vs 9.8 knots. Here $T$ req. is $6,689 \mathrm{kN}, R T$ is $6.432 \mathrm{kN}$ and $P$ req. is $60 \mathrm{~kW}$. In operational, the vessel used engine, panels and solar sail together or substitute depending on weather condition. When the propel by engine, the EI is $9268 \mathrm{~kg} /$ day of $\mathrm{CO}_{2}$. The optimum powered find out in combination no 8 (engine, panels and solar sail), the $E I$ is 0.14 .

3) On fishing ground: Vs 7 knots used renewable wind and solar some times substitute or together depending on situation. At the lower fishing speed ( 7 knots) the engine could be switched off and the fishing vessel powered by the a combination of sail and solar panels. The power without pollution and no disturb the fishes. The result of Power Combination shows in Table 5.

4) Homeward bound: the vessel in cargo weight condition at sailing speed Vs 9.8 knots. The HCFV possible using powered, as follows: in bad condition, used engine (60 $\mathrm{kW}$ ) and it produces emission index (EI) of 9,268 kg/day of $\mathrm{CO}_{2}$. In good condition, all of the configuration

Volume 5 Issue 7, July 2016 www.ijsr.net

Licensed Under Creative Commons Attribution CC BY 


\section{International Journal of Science and Research (IJSR) \\ ISSN (Online): 2319-7064}

Index Copernicus Value (2013): 6.14 | Impact Factor (2015): 6.391

possible to used as shown in Table 6. But, the optimum powered could be achieved when the vessel using combination no 8 (engine, panels and solar sail) because the $E I$ is 0.14

5) Arrival at Port: Vs 3 knots, used renewable solar panels some times substitute or together depending on situation.

The second discussion is how to applied the hybrid system could works in a combine power (engine, sail, PV) to propel the vessel. In this case, a combination various propulsors, which convert power available into useful thrust throughout: propeller and sail. To run the propeller, supplies power coming from engine and electric motor. Conventional engine needs converting the energy of the fuel into useful thrust $(T)$ and leaning produce emission. PV panels were used to absorb energy from sun-rays and then saved it into battery, then battery supplies power to run electric motor and no pollution. The main propulsion as well as sail with purpose to propel a sailing vessel.

Figure 4 shows correlation between $T p$ and $T s$ at $V s 3$ knots with mathematic function is $T p+T s=0.115$

Figure 5. Correlation between $P p$ and $P s$ at $V s 7$ knots with mathematic function is $P p+P s=7.04$

Figure 6 shows correlation between $T p$ and $T s$ at $V s 7$ knots with mathematic function is $T p+T s=3.235$

Figure 7. Correlation between $P p$ and $P s$ at $V s 7$ knots with mathematic function is $P p+P s=20.43$

Figure 8 shows correlation between $T p$ and $T s$ at $V s 9.8$ knots with mathematic function is $T p+T s=6,689$.

To find out value $T p$ and $T s$ at $V s 9.8$ knots is throughout the simple way. For example: when $T s=0 T p=6.763$, when $T s$ $=0.25$ Treq mean $T p=0.75$ Treq. and so on. This is the explanation of equilibrium $T p$ and $T s$ works in hybrid system

Figure 9. Correlation between $P p$ and $P s$ at $V_{S} 9.8$ knots with mathematic function is $P p+P s=60$. When the vessel uses individual power by engine (1), PV panels (2), sail (3) each produces thrust $(\mathrm{T})$ is $6,689 \mathrm{kN}$ or its similar with power 60 $\mathrm{kW}$, as a power used to propel the vessel at the service speed $\left(V_{s}\right) 9.8$ knots

In order to reduce the index of energy, a decrease in propulsive power must be achieved and/or improvements made in engine efficiency with a reduction in $s f c$. Improvements in efficiency of propulsion will lead directly to improvements in the economic return and a decrease in greenhouse gas effect (GHG) emissions. This means that there is now a double incentive to pursue such efficiency improvements. The ones of potential savings in resistance can be achieved throughout hull form selection. There are, however, some possible technical changes that will decrease emissions, but which may not be economically viable.

\section{Conclusion}

Based on the above discussion, it is discovered that the optimum hybrid system of fishing vessel combination was found in the result of combining propulsion systems at sailing speed 3 knots shown in Table 4 with the optimum configuration was found in combination no 8 (Engine + Panel + Solar sail) and give emission index of 0,016 , at sailing speed 9.8 knots shown in Table 5 give emission index of 0.14 and finally, at fishing speed 7 knots shown in Table 6 produces emission index of 0.05 . and it produces the lowest emission index. Therefore, current study is found to be very useful in order to minimize the use of energy from fossil fuels and produces cleaner seas environment.

\section{References}

[1] Utama IKAP., Setyawan, D, Jamaluddin, A, Sugiarso, A., 2010, Development of Catamaran Fishing Vessel, IPTEK, Journal for Technology and Science, Vol.21, No.4.

[2] FAO Fishing Vessel, 2007, Available online at: http:// www.id.wikipedia.org.

[3] Korol I. and Latorre, R., 2010, Development of EcoFriendly Fishing Vessel An ecological vehicle powered by renewable energy, EVER Monaco.

[4] Utama, I K A P and Molland, A F, 2012, The powering of future ships taking into consideration economic viability and environmental issues, International Conference on Ship and Offshore Technology (ICSOT), Ambon, Indonesia.

[5] Hind JA, 1982, Stability and Trim of Fishing Vesselssecond edition, Fishing News Book Ltd, Farnham, Surrey, England.

[6] Santosa P.I., Utama, I.K.A.P., Aryawan W.D., Purwanto D.B., Chao R.M., Nasirudin A., 2013, An Investigation Hybrid Catamaran Fishing Vessel, Journal Proceeding and Int. Conference Aptec, ITS-Surabaya, Indonesia.

[7] Molland AF, Turnock SR, Hudson DA, 2011, Ship Resistance and Propulsion - Practical Estimation of Ship Propulsive Power, ISBN:978-0-521-76052-2 Hardback, CUP, USA.

[8] Insel, M and Molland, A F, 1992, "An investigation into the resistance components of high speed displacement catamarans", Transactions of the Royal Institution of Naval Architects, RINA,Vol. 134.

[9] Utama, IKAP and Santosa, PI., Nasirudin A., Chao RM., 2013, New concept of solar powered catamaran fishing vessel, APAC, Hasanuddin University, Bali, Indonesia.

[10] Norwood, J., Jr., 1979, High Speed Sailing-Design Factor-A Study of High Performance Multi hull Yacht Design, ISBN: 0-396-07738-2, Publish in USA by Dodd, Mead \& Company, Inc.

[11]Larson L., 2007, Principles of Yacht design, $3^{\text {rd }}$ ed., ISBN-13: 9780071487696, Mc Graw Hill

[12] Kinney, F.S., 1977, Skene's Element of Yacth Design, ISBN: 071361823x, ACB Ltd, London.

[13] Marchaj, C A, 2003, Sail Performance, Techniques to Maximize Sail Power, Revised Edition, Adlard Coles Nautical, London 


\section{International Journal of Science and Research (IJSR) \\ ISSN (Online): 2319-7064}

Index Copernicus Value (2013): 6.14 | Impact Factor (2015): 6.391

\section{Author Profile}

PI Santosa is PhD student in Department of Naval Architecture and Shipbuilding Engineering Institut Teknologi Sepuluh Nopember (ITS) Surabaya, Indonesia.

I.K.A.P Utama is Professor, Dept. of Naval Architecture and Shipbuilding Engineering, Institut Tenologi Sepuluh Nopember (ITS), Indonesia.

W.D Aryawan is Head of Dept. Naval Architecture and Shipbuilding Engineering, Institut Tenologi Sepuluh Nopember (ITS), Indonesia. 